DOI https://doi.org/10.30525/978-9934-588-80-8-2.34

\title{
ХАРАКТЕРИСТИКА СУЧАСНИХ МЕТОДІВ ВИКЛАДАННЯ ПРАВОВИХ ОСВІТНІХ КОМПОНЕНТ У ЗАКЛАДІ ВИЩОЇ ОСВІТИ
}

\author{
Гришко В. I. \\ кандидат педагогічних наук, \\ дочент кафедри спецііальних юридичних дисичилін \\ Національний університет водного господарства \\ та природокористування \\ м. Рівне, Україна
}

Процес реформування вищої юридичної освіти, прийняття Стандартів першого (бакалаврського) та другого (магістерського) рівнів вищої освіти спеціальності 081 Право, акцент на формуванні у майбутніх юристів необхідних soft skills, зумовлюють необхідність кардинальних змін до процесу розробки та викладання освітніх компонент. Особливого значення набувають такі методи навчання, які могли б стимулювати самостійну діяльність майбутніх правознавців під час вивчення й закріплення матеріалу, розвивати навики професійної компетентності та формувати комплекс м'яких соціальних навичок. Від методів навчання залежить засвоєння змісту освіти, накопичення соціального і професійного досвіду студентів-правознавців.

Вважаємо, що методи навчання, зокрема 3 правових дисциплін, варто розглядати насамперед з точки зору тих пізнавальних операцій, які майбутні правознавці виконують під час вивчення права під керівництвом науково-педагогічного працівника. Тому, провідне місце варто відвести таким активним методам, як аналітико-синтетичний та евристичний.

Аналітично-синтетичний метод навчання є основним, оскільки вся пізнавальна робота майбутніх правознавців - це, передусім, здійснення аналізу та синтезу. При формуванні правових понять студенти у своїй діяльності переважно узагальнюють і абстрагують. Окрім того, цей метод відповідає природі самого права. Ефективність використання цього методу буде залежати від співвідношення в роботі прийомів аналізу і синтезу, які залежать від природи досліджуваного матеріалу, етапу і завдання його вивчення, а також від психологічних здібностей $\mathrm{i}$ можливостей майбутніх правознавців. Варто зауважити, що до кінця роботи над темою частина аналітичної роботи зменшується, а 
синтетичної - збільшується. Наприклад, використовуючи зазначений метод під час вивчення дисципліни «Цивільний процес», доречно запропонувати правознавцям вирішити таку ситуативну задачу: Позивач (Пасічнюк Олена) звернулася до суду з позовом до Пасічнюка Михайла про розірвання шлюбу. Від даного илюбу мають двоє повнолітніх дітей. Спільне життя з відповідачем не склалося, у них різні характери, різні погляди на життя. Оскільки подальше спільне життя стало неможливим, а збереження илюбу суперечить інтересам кожного із них, просить илюб з відповідачем розірвати. Між ким виникли циивільні правовідносини? Який юридичний факт $\epsilon$ підставою їх виникнення? В якому складі суду буде розглядатися справа?

Евристичний метод направлений на саму суть пізнавальних процесів, їх активізацію [1, с. 142]. Наприклад, його варто використовувати під час проблемного викладу матеріалу, підготовці проблемних евристичних діалогів, вправ проблемно-пошукового характеру, створення певної проблемної ситуації, організації колективного пошуку оптимального варіанта розв'язання проблеми, наприклад шляхом обговорення, «ініціативних» дій учасників тощо. Так, під час обговорення фабули такої справи: Під час розгляду справи в судовому засіданні за позовом громадянки Кривун до ї̈ чоловіка про стягнення аліментів на дитину, суд встановив, щуо позивачка знаходиться в зареєстрованому илюбі з відповідачем і їи 17 років. Тому суд зробив висновк, щуо позивачка не володіє процесуальною дієздатністю та, у зв'язку з ичим, виніс ухвалу про залишення заяви без розгляду - майбутні правознавці повинні колективно знайти оптимальну відповідь на запитання Чи допустив суддя порушення вимог процесуального закону?

Досліджуючи зміст евристичного методу, дидакти I. Лернер i М. Скаткін виділяють його різновиди: проблемний (проблемного навчання), пошуковий, або частково пошуковий, дослідницький [2].

Як показує наш досвід, сутність проблемного методу навчання полягає в створенні науково-педагогічним працівником проблемної ситуації, в постановці перед майбутніми правознавцями проблемних питань, в залученні студентів до процесу вирішення проблемних завдань, в результаті чого майбутніми правознавцями засвоюється досвід правової діяльності і формуються їхні творчі здібності. Проблемна ситуація - це ситуація, що породжує задачу і необхідність їі вирішення; майбутні правознавці повинні не тільки з'ясувати, що відомо і що треба знайти, перевірити, але i знайти нові, невідомі раніше способи вирішення. Проблемна ситуація передбачає зацікавленість майбутніх правознавців, потребу рішення, творчий внесок у роботу. Наприклад, 134 
варто запропонувати майбутніми правознавцями вирішити таку проблемну ситуативну задачу: 10 жовтня 2014 року до Рівненського районного суду м. Рівне звернулося ТзОВ «Нива» з позовом про стягнення заборгованості за угодою про надання послуг стільникового мобільного зв'язку. У позовній заяві позивач просив стягнути власне суму заборгованості за розмови, а також інфлячійні та процентні нарахування, пеню. 28 листопада 2014 року Рівненський районний суд м. Рівне на підставі зазначеної позовної заяви видав судовий наказ. Це передбачає попередній аналіз ситуації, визначення допущених судом помилок та пошук альтернативних рішень відповідно до чинного законодавства.

За допомогою пошукового методу можна підготувати майбутніх правознавців до самостійної дослідницької діяльності. Він передбачає бачення проблеми, вміння ставити питання; знаходити і самостійно будувати доказ, обгрунтування; робити висновки з накопичених фактів; висловлювати пропозицію (гіпотезу); будувати план перевірки i підтвердження гіпотези; ділити складне завдання на ряд більш дрібних, приватних i вирішувати їx. Викладач лише керує зазначеними вміннями. Цей метод забезпечує високий рівень розумового розвитку майбутніх правознавців.

Суть дослідницького методу полягає в активному використанні прийомів, що забезпечують залучення самих здобувачів вищої освіти до спостереження і накопичення правових фактів, на основі чого вони встановлюють зв'язки між правовими явищами, роблять узагальнення, висновки, пізнають правові закономірності. Під час реалізації цього методу використовують різні прийоми (пояснення, робота 3 конкретними нормативними правовими актами і т.д.), які в різних класифікаціях виступають як самостійні методи навчання. Дослідницький метод $\epsilon$ вищою формою прояву пізнавальної активності майбутніх правознавців, оскільки спрямований на розвиток у них творчого самостійного мислення, активізацію пізнавальної діяльності, формування навичок нестандартного вирішення певних професійних проблем і професійного спілкування.

Під час реалізації цих різновидів евристичного методу передбачається активна і самостійна діяльність майбутніх правознавців при вмілому керівництві нею науково-педагогічним працівником, який може використовувати різні прийоми: бесіду, демонстрацію, роботу 3 нормативними правовими актами, роботу з таблицями, схемами тощо

На наш погляд, одним із найефективніших засобів практичної підготовки майбутніх правознавців, які дають можливість підвищити ефективність навчання та якість знань, а також сформувати необхідні 
професійні вміння майбутніх фахівців $є$ інтерактивні методи навчання [3]. Інтерактивні методи передбачають режим взаємодії, діалогу, двостороннього обміну інформацією та орієнтовані на взаємодію майбутніх правознавців не тільки з науково-педагогічним працівником, але i один 3 одним, комп'ютером, інтерактивним підручником, навчальним посібником.

Таким чином, інтерактивні методи навчання можна розглядати як найсучаснішу форму активних методів, засновану, насамперед, на комунікації та умінні працювати в команді. Аналітичне дослідження методичної літератури дозволило нам констатувати, що складно класифікувати інтерактивні методи, оскільки у багатьох із них поєднано одразу кілька прийомів. Ми об'єднанали методи в групи, насамперед за цілями їх використання, щоб виділити найбільш поширені: 1) методи навчального спілкування (сократівські методи, дискусія, диспут, полеміка, «круглий стіл», рольові ігри, ігриінсценізації, імітаційні ігри,); 2) методи, у яких переважає навчальна співпраця (робота у мікрогрупах, дидактичні ігри з наявністю спільного предметного матеріалу); 3) форми інтерактивної взаємодії, у яких однаково поєднано навчальне спілкування і співпрацю (кейс-метод, метод проектів, мозковий штурм, театралізована гра, гра-драматизація).

Отже, в процесі професійної комунікативної підготовки майбутніх правознавців особливе значення мають активні та інтерактивні методи навчання, оскільки використання інтерактивних методик, заснованих на навчанні професійним мовним навичкам через дію, відтворює ситуації, взаємини, завдання, характерні для повсякденної роботи правників. Інтерактивні методики, які використовують у навчальнонаукових лабораторіях, студенти сприймають як найбільш природнє середовище для демонстрації навичок і прояву професійних якостей у студентів-правознавців.

\section{Література:}

1. Бордовская Н. В., Реан А. А. Педагогика: учебник для вузов. СПб.: Питер, 2003. 304 с.

2. Лернер И. Я. Дидактические основы методов обучения. М.: Педагогика, 1991. 185 с.

3. Гришко B.I., Юхимець О.I. Правова комунікація в умовах інтеграційних процесів: навчально-методичний посібник для здобувачів вищої освіти першого (бакалаврського) рівня. Рівне: ТМ «Доцент», 2018. $121 \mathrm{c}$. 